\title{
Transmission and Translation
}

Thomas Williams

As I write these words, I can see on my shelves an attractively bound set of sixteen volumes, each bearing on its spine the words "J. Duns Scotus Opera Omnia." One would be tempted to assume that these are The Complete Works of John Duns Scotus. Unfortunately, in medieval philosophy things are rarely so simple. Some of the works included in this set are not by Scotus at all, but were once attributed to him. Some of Scotus's genuine works, including his early Lectura on the Sentences of Peter Lombard, are not included. And what this set presents as Book 1 of Scotus's late (and very important) Reportatio is actually not the Reportatio at all, but another work whose authenticity and authority are vigorously disputed.

And there are further problems. The attractive modern binding belies the age of the edition itself. Open up any of the books, and what you will see is a photographic reprint of an edition first published in 1639. That edition (known as the Wadding edition, after its editor) is not a critical edition, made by weighing all the manuscript evidence according to established principles of textual scholarship in order to determine, with as much precision and certainty as possible, exactly what Scotus said or wrote. In many cases the editor simply looked at the one or two manuscripts he had handy and transcribed what he found there, sometimes without much attention to whether the resulting text even made good sense. Sadly, for much of Scotus's work this faulty edition is the best one we have. So one has to use it: but one has to use it with great care.

The pitfalls of the Wadding edition illustrate a general feature of the study of medieval philosophy: the gap that separates the authentic words of the medieval thinker one wishes to study from the Latin words one sees on the pages of a printed edition - and further still from the English words one sees in a translation. The aim of this essay is to make clear both the nature and the size of that gap, not in order to dismay prospective students of medieval philosophy, but in order to explain the hazards in such a way that students can equip themselves properly to meet them. I will begin by discussing in a general way the channels of 
transmission by which medieval philosophy has made its way down to us. I then turn to three specific cases by which I illustrate some of those general points as they apply to texts of different sorts and from different periods. Along the way I draw attention to the kinds of errors that are liable to be introduced at the various stages of transmission between a medieval lecturer's spoken words and the text of a modern critical edition, and I outline the tools and techniques that the careful historian of medieval philosophy will use in order to minimize such errors, especially where no critical edition is available.

In the second half of the essay I turn to problems of translation. I provide an example that shows how a reader can sometimes detect errors in a translation even without checking the Latin text, and another to illustrate how translations sometimes reflect controversial views about how a text is to be interpreted. I then conclude with a look at the translation of particular terms, discussing a number of standard translations that are apt to be misleading, and giving some idea of the range of translation of certain key terms.

\section{Channels of Transmission}

In the ideal case we would have a carefully constructed and easily legible autograph (that is, a text in the author's own handwriting). Such ideal cases are exceedingly rare. Even in the few instances in which we do have autographs, the text can pose problems. An author can be careless about checking his work, or his handwriting can be dreadful. Aquinas, for example, is notorious for absent-mindedly setting down wrong words or phrases, and his handwriting is so difficult to read that only a handful of specialists can decipher it.

In default of autographs (whether reliable and legible or not), we must rely on texts that are conveyed to us by some number of intermediaries. These range from (at one extreme) copies that were authenticated by the author himself to (at the other) distant descendants of lecture notes first recorded by a scribe who may not even have completely followed the discussion he was recording. Particularly in the days when philosophy was largely carried on orally, through lectures and formal public disputations, the number of intermediaries between an author and our text, and hence the occasions on which errors and corruptions could be 
introduced, might be worrisomely great. ${ }^{1}$

For example, any given lecture (or series of lectures) might exist in two versions from the very beginning: one dictated by the master himself and another taken down by the students who attended. A statute of the University of Paris dated December 10, 1355, requires that masters of philosophy "utter their words rapidly so that the mind of the hearer can take them in but the hand cannot keep up with them," that they in fact speak "as if no one were taking notes before them." ${ }^{2}$ Where this was the practice, student reports, called reportationes, were especially likely to contain omissions, mistranscriptions, and misunderstandings. Other students could make copies of such reportationes, thereby increasing the number of competing versions of one and the same lecture or disputation. Disputations were especially likely to generate discrepant reportationes, since not only were they more complex (and less orderly) than lectures, but they could also be reported either with or without the master's determination of the question.

A master who wished to establish a more definitive version of his text, an ordinatio, would revise and polish either his own notes or a student reportatio and present it to the university's official booksellers, or stationarii, for distribution. (When historians speak of "publishing" a work of scholastic philosophy, it is this official submission to the stationarii that they have in mind.) In making an ordinatio the master might reformulate certain arguments or add new material. Some errors in the original text might be corrected, but new ones could easily be introduced, especially if substantive revisions were not carried out consistently throughout the text. Often several years passed between the original lectures and the ordinatio; a master might choose to update his work to accommodate developments in his views in the meantime, but he might instead treat the earlier lectures as having a literary integrity of their

${ }^{1}$ The best summary account remains that of Kenny and Pinborg 1982, 34-42, on which I rely heavily in what follows. More detailed treatments of the channels of transmission may be found in Destrez 1935, Dondaine 1956, and Fink-Errera 1960 and 1962.

${ }^{2}$ Chartularium universitatis Parisiensis, III, 39-40, translated in Thorndike 1944, 237-238. The practice of reading at such a pace is presented as already common; the decree simply forbids the alternative practice of dictating slowly. The decree is explicitly applied to both lectures and disputations. Student resentment was apparently expected, since the decree provides for stiff penalties for "listeners who oppose the execution of this our statute by clamor, hissing, noise, [or] throwing stones by themselves or by their servants and accomplices." 
own and refrain from substantial revisions.

The ordinatio would then circulate, not as a whole, but in units called peciae, unbound sets of (usually) 16 pages each. As Jan Pinborg explains:

since the stationarius normally has at least two sets of peciae of a given text, more or less identical, and since the peciae are hired one by one, any copyist may be combining peciae from two different sources into his copy, thus making different parts of his text of different critical value. Moreover, the pecia in itself is not a stable entity; it will suffer wear and tear, so that words or even whole sentences may have become difficult to read, corrections and marginal remarks (often totally irrelevant to the text) may have been added by less conscientious borrowers, etc. ... We even have indications that some texts were changed so as to offer more acceptable doctrines. ${ }^{3}$

Further errors and changes could easily be introduced by copyists who were not philosophically sophisticated enough to understand the text well, others who were being paid piecework for their copying and had therefore a greater incentive for speed than for accuracy, and still others who were not interested in the text for its own sake but merely wanted to make copies of the bits they found useful. Some copyists simply became tired. And Anneliese Maier quotes a disgruntled copyist who refused to copy "a whole page of totally useless material" from Walter Burley. ${ }^{4}$

Error-prone though they undoubtedly are, these manuscripts are in some cases our only sources for a text, and in others they are an indispensable resource for correcting non-critical editions. A present-day user of manuscripts needs the specialized skills taught under three general headings: paleography, text editing, and codicology. Paleography is simply the study of writing. One needs some acquaintance with the variety of handwriting to be found in manuscripts, but what is especially important is familiarity with the complex system of abbreviations that scribes employed in order to save time and economize on writing materials. Fortunately, a modest competence in this field - enough to be of great help to a medievalist in philosophy who does not wish to be primarily a textualist - is surprisingly easy to acquire.

${ }^{3}$ Kenny and Pinborg 1982, 37-38. See also Pollard 1978, and for detailed information on book production in the late medieval university, see Bataillon et al. 1988.

${ }^{4}$ quoted in Kenny and Pinborg 1982, 41. 
One can get a good start by taking a one-semester course in medieval paleography or even by working through a paleographical manual on one's own. ${ }^{5}$ Codicology, strictly speaking, is simply the study of codices (manuscript books). Its value for historians of medieval philosophy is that it can sometimes help in retracing the process of transmission. Text editing is the study of the principles and techniques by which we determine the reliability and relative priority of particular manuscripts, identify families of related manuscripts, and (ideally) reverse the incremental changes introduced by successive copyists so as to produce a text as close as possible to the original. ${ }^{6}$

The next step in the process by which medieval philosophical texts have been transmitted to the present day is the early printed edition. As will become clear in the case studies below, these early editions are not especially scholarly. Nonetheless, they are our only printed source for some medieval texts, and in cases where the manuscripts from which they were derived are no longer extant, they provide an independent witness to the text that can be taken into account in a critical reconstruction. Modern critical editions are the final step. Modern editors take into account all the manuscript evidence (and that of early editions where these give an independent witness), form hypotheses about the development of the manuscript tradition and the relative critical weight of various manuscripts, and reconstruct the original text according to established principles of textual scholarship. But it is important to realize that even critical editions are not infallible. Some editorial decisions, for example, depend upon an editor's judgment about which reading gives the best philosophical sense in context; and that judgment may be disputable on philosophical grounds. Fortunately, critical editions provide an apparatus of variant readings, so that skeptical readers have at their disposal the information they need when a passage seems suspect. Moreover, the punctuation of a text - including

${ }^{5}$ For this purpose I recommend Bischoff 1990. The standard manuals of abbreviations are Capelli 1961 and Pelzer 1966. Knowledge of abbreviations is useful not only for reading the manuscripts but also for detecting errors, since mistakes in copies are often attributable to misreading of abbreviations: see Bergh 1978.

${ }^{6}$ Courses in paleography often include instruction in codicology and text editing, which are best learned through instruction and apprenticeship. Text editing in particular is difficult to encapsulate in a general handbook, since different kinds of texts call for different editorial techniques. 
sentence and paragraph divisions - is almost wholly editorial, since the manuscripts generally employ what might be called the random-dot method of punctuation, which is of almost no value as a guide to the sense of the text. Now it is not uncommon to find misleading or outright mistaken punctuation even in critical editions, and such mistakes can drastically alter the sense of a passage. The best advice is simply to ignore editorial punctuation altogether.

\section{Three Case Studies}

One can get a better sense of the varied fates of medieval philosophical texts by examining the works of specific thinkers. Here I offer three case studies, brief narratives of the channels by which the works of Anselm of Canterbury (1033-1109), John Duns Scotus (1225/61308), and Robert Holcot (d. 1349) have come down to us. The case studies have two aims. First, they are meant to give the reader a general idea about what to watch out for when studying medieval philosophy. The general lesson is that it is highly advisable, before undertaking serious work on a medieval philosopher, to acquaint oneself with the state of the manuscripts and editions of his work. More specific cautions will, I trust, become evident along the way. Second, the case studies are also meant to show how much textual and editorial work is yet to be done in medieval philosophy. Since it seems impossible to make any informative general statements about how much interesting work remains to be done along these lines, I have chosen three thinkers for whose works we have texts of quite different levels of reliability.

\section{Anselm}

Many of the complexities in the process of transmission fortunately do not apply to Anselm's works, since they began life as written works and not as lectures. Moreover, we have at least one manuscript (Bodleian 271) whose scribe we can identify with reasonable certainty as a monk of Canterbury Cathedral known to have been in correspondence with Anselm himself

\footnotetext{
${ }^{7}$ A thorough discussion of the transmission of Anselm's works can be found in Schmitt 1968, I: 1*-239*, from which my remarks are derived.
} 
about the correct reading of a passage in De conceptu virginali. ${ }^{8}$ Anselm himself seems to have been especially conscientious about revising and perfecting his works before allowing them to be copied, although he does complain in one place that "certain over-hasty persons" have copied his dialogues in the wrong order, ${ }^{9}$ and Anselm does sometimes go back and make minor revisions and improvements. For example, the Proslogion originally had a different title and no chapter divisions. In this connection it is worth noting that chapter headings in medieval texts are often additions by later scribes, a point occasionally lost on interpreters who seek to make exegetical hay out of such inauthentic texts. The chapter titles in Anselm's works, however, originated with the author himself. It is their placement in modern editions and translations that is inauthentic: Anselm put the whole list of chapter titles at the beginning of a work and did not repeat them within the text itself. ${ }^{10}$

The early printed editions of Anselm are of almost no critical value. The first such edition, published in Nuremburg in 1491, was edited by an otherwise obscure scholar named Petrus Danhauser. F. S. Schmitt comments,

It is not known which manuscript or manuscripts he used as the basis for the edition. To judge from the way the edition turned out, both on the whole and in details, they must have been exclusively late manuscripts that were easily accessible. Moreover, we cannot escape the impression that every now and then the young humanist laid an improving hand on the text that had come down to him. ${ }^{11}$

Since most later editions followed his text more or less uncritically, they are equally unreliable. Indeed, some editions actually made matters worse by adding to the number of inauthentic works Danhauser had included under Anselm's name. Not until the edition of Gabriel Gerberon in 1675 do we find an attempt to correct the received text on the basis of a large number of manuscripts, along with something approaching an apparatus of variant readings; but even then, the oldest and best manuscripts were not used. The critical edition of F. S.

${ }^{8 S c h m i t t ~ 1968, ~ I: ~ 226 *-239 * . ~ S o u t h e r n ~ 1963, ~} 238$ n., argues against Schmitt's attribution.

'See the Preface to De veritate, De libertate arbitrii, and De casu diaboli, translated in Williams 2002.. ${ }^{10}$ Schmitt 1968, I: $37^{*}$.

${ }^{11}$ Schmitt 1968, I: 10* (my translation). 
Schmitt, published in 1968, was therefore in essence a wholly new undertaking. Schmitt's edition is unusual in that it contains all the authentic completed works of a medieval philosopher as edited by a single hand and published in a single series, ${ }^{12}$ making the present state of Anselm's texts enviably unproblematic. Only rarely have I found reason to question Schmitt's editorial decisions about which of a number of variant readings to accept; even the paragraphing shows great sensitivity to Anselm's text. So the student of Anselm's works can, to a remarkable degree, simply assume the reliability of the Latin text.

\section{John Duns Scotus}

As I have already suggested in my introduction, Scotus's works have come down to us in a particularly confusing state. Even the briefest attempt to tell the story of all his works would require far too much space here, ${ }^{13}$ so here I will illustrate the difficulties by discussing Scotus's Ordinatio, the revision of the lectures he gave as a bachelor at Oxford in the late 1290s. The basis for the revision was his original lecture notes, the Lectura. We can clearly discern at least two layers of revision. The initial revision was begun in the summer of 1300 and left incomplete when Scotus departed for Paris in 1302; it probably did not get much past Book 2. Further revisions were made in Paris; we know that Scotus was still dictating questions for Book 4 as late as 1304, as well as updating the parts he had already revised while still at Oxford. These updates were usually in the form of marginal additions or interpolated texts that reflected what Scotus taught in Paris. Our picture of the nature and extent of the second layer of revisions is, however, still murky, in part because the Vatican edition of the Ordinatio has reached only to Book 2, d. 3, and no critical edition of the Paris Reportatio is available at all. ${ }^{14}$ Much further study is needed in order to understand just how much the Ordinatio represents

\footnotetext{
${ }^{12}$ Admittedly, it was originally published in separate volumes by different publishers, but it was reissued as a single set, with additions, corrections, and a long critical preface, by Friedrich Fromann Verlag in 1968.

${ }^{13}$ See my summary account in Williams (forthcoming).

${ }^{14}$ Complicating matters even more is the fact that there are rival Reportationes of Scotus's Paris lectures: four on Book 1 (including a version examined by Scotus himself and therefore known as the Reportatio examinata), two on Book 2, four on Book 3, and two on Book 4.
} 
the views Scotus held at Oxford and how much he revised it to reflect developments in his views in Paris. At present, however, the most plausible view would seem to be that of Allan B. Wolter, who wrote that it is a

serious and inexcusable mistake for scholars writing on Scotus today to regard his Ordinatio as a seamless garment rather than a work begun in Oxford and left unfinished when he left Paris for Cologne. It is particularly unwise to consider the basic text of the eleven volumes of the Vatican edition so far printed as necessarily representative of his final views simply because parts were updated with a view to what he taught later in Paris. ${ }^{15}$

And Wolter argues persuasively that Book 1 of the Ordinatio (the only book for which there is a complete critical edition) "is simply a more mature expression of his early views, and needs to be supplemented by the later positions he held which can be found in the reports of his lectures at Cambridge and Paris" 16 - reports that for the most part have never been edited. ${ }^{17}$ The paleographical skills needed to read the manuscripts of these reportationes, as well as those of the parts of the Ordinatio that have not yet been critically edited, are therefore highly desirable for a serious student of Scotus. The Vatican editors have already determined which manuscripts of the Ordinatio are most reliable, but modest skills in text editing are needed in order to weigh the merits of variant readings in those manuscripts, and in the few available manuscripts of the Reportationes. ${ }^{18}$

\section{Robert Holcot}

The Oxford Dominican Robert Holcot is one of the many important medieval philosophers who have been seriously underappreciated and understudied. Although modern

\footnotetext{
${ }^{15}$ Wolter 1996, 39-40.

16Wolter 1996, 50.

${ }^{17}$ The exception for Book 1 is the version identified by the Vatican editors as Reportatio 1B of the Paris lectures, which does exist in an edition published in Paris in 1517. But as we have seen, early printed editions must be used with caution, and in any event Reportatio $1 \mathrm{~B}$ is of far less value than the hitherto unedited Reportatio examinata (Reportatio 1A).
}

${ }^{18}$ Noone 1998 contains an edition of Reportatio 1A, d. 36, with a discussion of the manuscripts on pp. 392394. All the known manuscripts of Scotus's work are listed in the Prolegomena to the first volume of the Vatican edition, pp. $144^{*}-154^{*}$. 
interest in Holcot has been somewhat sporadic, his influence in the late Middle Ages was great, as is evidenced by the great number of fourteenth- and fifteenth-century manuscripts of his work. ${ }^{19}$ There are 48 manuscripts of his questions on the Sentences (compare this to the 36 manuscripts of Ockham's Sentences commentary) and an astonishing 175 manuscripts of his commentary on the Book of Wisdom, a work that influenced Chaucer's Nun's Priest's Tale. ${ }^{20}$ He made important contributions to semantics, the debate over God's knowledge of future contingents, discussions of predestination, grace, and merit, and philosophical theology more generally. Here I will discuss only the fate of his questions on the Sentences.

Katherine Tachau comments that "for Holcot's Sentences questions . . . the evidence is strong that the pecia system was the basis for their dissemination." ${ }^{21}$ Many manuscripts bear the traces of this system, as in a scribe's "crowding the margins with text for which he had not left sufficient room when copying peciae out of order, as they became available." 22 In some cases substantial portions of the text clearly dropped out in the course of transmission. Thus, in two early manuscripts, one counterargument to an earlier objection in Book 2, q. 2, breaks off after just two sentences, and the counterarguments to the next three objections are missing altogether. Afterwards come the counterarguments to four more objections. In somewhat later manuscripts, those last four counterarguments have also dropped out, "almost certainly by the loss of a folio from an unbound quire."23

A text of Holcot's questions on the Sentences was printed at Lyon in 1497. In a cover letter to this edition Jodocus Badius notes that the scholar entrusted with reviewing the manuscripts had found the text in a disorderly state, and that the manuscripts available did not allow him to establish a reliable text. Unfortunately, this edition is the only printed version of

\footnotetext{
${ }^{19}$ See Streveler and Tachau 1995, 2-3, 36-38. Katherine Tachau's introduction to this volume is a very informative source for information about Holcot's career and the transmission of his works; my discussion of the transmission of the Sentences questions is based on pp. 35-46.

20Pratt 1977.

${ }^{21}$ Streveler and Tachau 1995, 41.

${ }^{22}$ Ibid.

23Ibid., 45.
} 
the Sentences available today. ${ }^{24}$ No complete collation of the manuscripts of Holcot's Sentences questions has yet been made, and as far as I know, no critical edition is in preparation.

Accordingly, Holcot is an outstanding example of a medieval thinker whose works offer a ripe field for both textual and philosophical study.

\section{Translating Medieval Philosophy}

We can think of English translations as the last, and inevitably the most problematic, step in the transmission of medieval philosophical texts. It is, of course, a very necessary step, not only for the wider dissemination of medieval philosophy to those who are interested in the subject but do not wish to become specialists, but also for the formation of specialists. For example, there is no telling how many people have been brought to a serious study of John Duns Scotus through the translations of Allan B. Wolter. More generally, it is surely no accident that the most widely translated medieval thinkers are also the most widely studied, for translations encourage study and studies encourage translation.

Given the aims of this essay, I wish to concentrate here on matters that readers of English translations need to be aware of in order to make the most effective use possible of those translations. I should note first of all that even a modest amount of Latin can be very useful in working with an English translation and Latin text side by side, especially for thirteenth- and fourteenth-century texts, with their generally simple syntax and limited, largely technical vocabulary. (One rarely has the luxury, so common with classical texts, of working with multiple translations of the same text, which can be enormously helpful.) However good a translation is, certain passages will be open to misunderstandings that the translator could never have foreseen, and a reader with a bit of Latin can put herself back on the right track immediately.

Some faulty translations can be detected, if perhaps not also remedied, without any knowledge of Latin at all. Consider the following passage from a widely used translation of

\footnotetext{
${ }^{24}$ Streveler and Tachau 1995 contains a partial edition of Book 2, q. 2. Holcot's Quodlibetal Questions are similarly neglected: four questions are edited in Streveler and Tachau 1995 and three in Gelber 1983, but otherwise the Lyon edition is the only printed source.
} 
Anselm's Proslogion:

[M]any words are used improperly, as, for example, when we use 'to be' for 'not to be', and 'to do' for 'not to do' or for 'to do nothing'. Thus we often say to someone who denies that some thing exists: 'It is as you say it is', although it would seem much more proper to say, 'It is not as you say it is not'. Again, we say 'This man is sitting', just as we say 'That man is doing [something]'; or we say 'This man is resting', just as we say 'That man is doing [something']. But 'to sit' is not to do something, and 'to rest' is to do nothing.

The penultimate sentence has to be mistaken, since as this translator has rendered it, it does not offer the example that Anselm has promised: that is, an example of 'to do' being used for 'not to do' or 'to do nothing'. Moreover, the sentence is not properly parallel to the preceding one, as the 'Again' leads us to expect it will be. So simply by paying philosophical attention to the content of the argument, we can know that there is something wrong with the translation. A look at the Latin enables us to correct it to read as follows:

Again, we say 'This man is sitting just as that man is doing' or 'This man is resting just as that man is doing', even though 'to sit' is not to do something and 'to rest' is to do nothing.

Now the passage gives the kind of example Anselm had led us to expect. It should be noted that the translation I quoted first is grammatically possible, given the Latin text; it just makes no philosophical sense. Similar mistranslations occur when translators attach modifiers, especially adverbial phrases, to the wrong element. Once again, philosophical attention is all that is needed to recognize the mistake, although recourse to the Latin text may be needed to correct it.

In other cases, a translation might make enough sense in context that one cannot recognize it as erroneous without comparing it to the Latin original. Compare these two alternative translations of a passage from John Duns Scotus, ${ }^{25}$ both of which make perfectly good sense in context:

${ }^{25}$ Ordinatio 4, d. 46, q. 1, n. 12: “dico quod non simpliciter est debitor nisi bonitati suae, ut diligat eam; creaturis autem est debitor ex liberalitate sua, ut communicet eis quod natura sua exigit, quae exigentia in eis ponitur quoddam iustum, quasi secundarium obiectum illius iustitiae; tamen secundum veritatem nihil est determinate iustum et extra Deum nisi secundum quid, scilicet cum hac modificatione, quantum est ex parte creaturae, sed simpliciter iustum tantummodo est relatum ad primam iustitiam, quia scilicet actualiter volitum a divina voluntate." 
A I say that God is no debtor in any unqualified sense save with respect to his own goodness, namely, that he love it. But where creatures are concerned he is debtor rather to his generosity, in the sense that he gives creatures what their nature demands, which exigency in them is set down as something just, a kind of secondary object of this justice, as it were. But in truth nothing outside of God can be said to be just without this added qualification. In an unqualified sense where a creature is concerned, God is just only in relation to his first justice, namely, because such a creature has been actually willed by the divine will.
B I say that God is a debtor, in an unqualified sense, only to his own goodness, that he love it. To creatures, however, he is a debtor in virtue of his generosity, that he communicate to them what their nature requires. This requirement is set down as something just in them, as a secondary object of God's justice. But in truth nothing external to God is just except in a certain respect, viz., with the qualification "so far as it is on the part of a creature." The unqualifiedly just is only that which is related to the first justice, i.e., because it is actually willed by the divine will

Note first that Translator A says that God is a debtor to his generosity, whereas Translator B says that God is a debtor in virtue of his generosity. This discrepancy is instructive because it reveals the extent to which translations are at the same time philosophically motivated (and therefore possibly tendentious) interpretations of the text being translated. In a number of influential articles and books, Translator A has argued that according to Scotus, God owes it to himself to make his creatures good, so that God's generosity to creatures is itself a matter of justice: justice to himself, not (strictly speaking) justice to creatures.. The expression "debtor to his generosity" would support that interpretation. Translator B, by contrast, has written a number of articles arguing that according to Scotus, God's justice to himself imposes no constraints on how he must treat individual creatures or the created universe as a whole. The words "a debtor in virtue of his generosity" are meant to suggest that it is solely a matter of generosity for God to give his creatures their characteristic perfections. ${ }^{26}$

The translations of the end of the passage also reveal an interpretive agenda at work. Scotus has identified God's "first justice" as his justice with respect to himself. When Translator A says that "God is just only in relation to his first justice" when he "gives creatures what their

${ }^{26} \mathrm{As}$ Richard Cross puts it, "the claim is not that God is essentially generous, but that the term 'debtor' is being used metaphorically" (Cross 1997, 63). 
nature demands," he conveys his view that in conferring perfections on creatures Scotus's God is being just, not really to his creatures, but to himself. By contrast, Translator B's rendering of the sentence supports his reading of Scotus as an extreme voluntarist: what is unqualifiedly just is simply whatever God wills.

In cases like these, where faulty translations cannot be detected simply by philosophical vigilance, the user of translations needs to be able to form a judgment as to the general reliability of a translator. Consulting more senior medievalists about a translator's reputation can be helpful, but care is needed here, especially when the medievalists one consults are translators themselves, since translators seem to be temperamentally disposed to exaggerate the shortcomings of the works of others. ${ }^{27}$ A better approach is to form one's own judgment about the translator's philosophical acuity by reading a representative selection of her articles. A sloppy philosopher will be a sloppy translator; an unreliable interpreter will be an unreliable translator. Indeed, to a limited extent, the translator's prose style is a good guide to the quality of her translations. A translator who habitually writes hazy English will produce hazy translations, but one who writes with precision will translate with precision. It is probably also true that someone who writes elegant English will produce elegant translations, but elegance, though gratifying to the reader, is seldom of philosophical significance, and the desire for elegance is a standing temptation to stray from strict fidelity to the text.

\section{Pairs and Snares}

Strict fidelity to the text of course requires sound judgment in the choice of translations for individual words, and such judgment depends as much on philosophical sensitivity and an appreciation of English idiom as it does on one's command of Latin. In this section I wish to illustrate the difficulties that face translators by discussing words that are commonly mistranslated and words that defy exact translation. I also note the range of translation of some key philosophical terms.

${ }^{27}$ I once heard a scholar dismiss an entire translation of the Proslogion because he disapproved of the rendering of one word in chapter two, even though I could see no philosphical difference at all between the alternative translations, only a trifling disagreement about what was the more idiomatic English. 
Most common mistranslations result from a lazy preference for cognates. Malitia is often translated as 'malice' and officiosum as 'officious', to take just two examples. Now malitia can mean 'malice' (a desire to inflict injury), but more often it means simply 'badness'. It is the opposite of 'goodness', not of 'benevolence'. Officiosum is most commonly seen in the threefold classification of lies as perniciosum, officiosum, and iocosum. To translate these as 'pernicious', 'officious', and 'jocose' is sheer laziness. 'Officious' means "meddlesome" or "offensively forward in offering help or advice." A mendacium officiosum, however, is not a meddlesome lie but a serviceable and (as such) inoffensive one. (The meaning "obliging" for English 'officious' has long been obsolete.) With both malitia and officiosum the correct translation is suggested not by the English cognate but by the Latin word formation: malitia is the abstract noun from malum, meaning "bad" - hence "badness"; officiosum is the adjective from officium, meaning "function" or "service" - hence "functional" or "serviceable." Attention to standard patterns of word formation when learning Latin is one of the best safeguards against this kind of mistake.

With malitia and officiosum perfectly good English equivalents are available but carelessly overlooked. For many other words there is no exact English equivalent, and one must make do with an approximation. There is, for example, no single English word that corresponds exactly to appetitus in its Aristotelian use: 'tendency', 'inclination', 'desire', 'directedness', and similar terms convey the right meaning in some contexts but not in others. The sensible convention is to use 'appetite' as the invariable translation of appetitus, on the understanding that readers will recognize 'appetite' as a term of art. Similar conventions justify the translation of potentia as 'potency' or 'potentiality', actus (in one of its senses) as 'act' or 'actuality', and accidens as 'accident'. However inexact such standard translations may be, they can hardly be called misleading, since any modestly well-trained reader of medieval texts will recognize them for the technical terms they are..$^{28}$ Indeed, there is some advantage to using

\footnotetext{
${ }^{28}$ Analogously, the standard rendering of eudaimonia as 'happiness' is as inaccurate as it is inevitable, but anyone who has heard even one lecture on Aristotle's Ethics knows exactly what is wrong with it and can effortlessly substitute the concept of eudaimonia, which no English word calls up, for the concept usually called up by the word 'happiness'.
} 
words like 'potentiality' that have no ordinary non-technical use.

Sometimes, however, it is not clear whether a word is a technical term or not, or even whether it is being used with exactly the same meaning throughout a text. Does honestum, for example, describe items all of which exemplify some single property in a given thinker's moral ontology (say, intrinsic value), or is it a more general term of commendation whose exact meaning in its different occurrences depends on context? If the first alternative is the case, a consistent translation of honestum is probably advisable, although what that consistent translation should be is likely to be a contentious matter of interpretation; if the second alternative is the case, a consistent translation of honestum would be downright misleading. And of course these two alternatives do not exhaust the possibilities. Nor does the fact that a certain word is a technical term in one author imply that it is a technical term in any other author. For that matter, one and the same author may use the same term both as a technical term and as a non-technical term even within a single work. Similar problems bedevil the translator faced with such protean terms as principium (beginning, origin, premise, principle, starting-point) and ratio (argument, basis, concept, definition, essential nature, feature, ground, intelligible nature, meaning, model, reason, theoretical account). As is so often the case, it is not facility in Latin but exegetical and philosophical acuity that allows the translator to determine how a word is being used and, accordingly, how it ought to be translated.

\section{A Word of Encouragement}

I have focused in this essay on the obstacles that confront the scholar of medieval philosophy. The reader should not suppose, however, that the work needed to overcome these obstacles is mere drudgery: far from it. As my colleague, Katherine Tachau, is fond of observing, doing paleographical work is like being paid to do crossword puzzles. Anyone who enjoys detective stories should enjoy codicological research and the editing of texts, which employ exactly the same skills of picking up clues and drawing inferences. And anyone who takes pleasure in finding just the right words to express a difficult philosophical thought should find deep satisfaction in the challenge of translation. 
Above all else, however, the effort to recover the authentic words of medieval philosophers is worthwhile simply because those words are so philosophically interesting. Even after a few decades of renewed attention to medieval thought, there remains an astonishing amount of first-rate philosophy - technically proficient, inventive in argument, and attentive to questions of perennial interest - that has yet to be examined. The effort required to make these texts available for study is amply repaid by the opportunity to reclaim the treasures of a rich philosophical inheritance. 


\section{Bibliography}

Bataillon, Louis J., Bertrand G. Guyot, and Richard H. Rouse, ed. 1988. La production du livre universitaire au moyen âge. Exemplar et pecia. Paris: Éditions du Centre national de la recherche scientifique.

Bergh, Birger. 1978. Palaeography and Textual Criticism. Lund: Liber Läromedel/Gleerup.

Bischoff, Bernhard. 1990. Latin Palaeography: Antiquity and the Middle Ages. Cambridge: Cambridge University Press.

Capelli, Adriano. 1961. Lexicon Abbreviaturarum. $6^{\text {th }}$ ed. Milan: Hoepli.

Cross, Richard. 1997. “Duns Scotus on Goodness, Justice, and What God Can Do." Journal of Theological Studies 48, 48-76.

Destrez, Jean. 1935. La Pecia dans les manuscrits univeritaires du XIIIe et du XIVe siècles. Paris: Éditions Jacques Vautrain.

Dondaine, Antoine. 1956. Les secrétaires de Saint Thomas. Rome: Editori di S. Tommasso.

Fink-Errera, G. 1960. “De l'édition universitaire.” In L'homme et son destin, d'après les penseurs du Moyen Age. Actes du 1er congrès international de philosophie médiévale, 221-8. Louvain: Nauwelaerts.

. 1962. “Une institution du monde médiéval: la pecia." Revue Philosophique de Louvain 60: 184-243.

Gelber, Hester Goodenough. 1983. Exploring the Boundaries of Reason: Three Questions on the Nature of God by Robert Holcot, OP. Toronto: Pontifical Institute of Mediaeval Studies.

Kenny, Anthony and Jan Pinborg. 1982. "Medieval Philosophical Literature." In The Cambridge History of Later Medieval Philosophy, edited by Norman Kretzmann, Anthony Kenny, and Jan Pinborg, 11-42. Cambridge: Cambridge University Press.

Noone, Timothy B. 1998. "Scotus on Divine Ideas: Rep. Paris. I-A, d. 36." Medioeve: Rivista di storia della filosofia medievale 24: 359-453.

Pelzer, Auguste. 1966. Abréviations latines médiévales. Supplément au Dizionario di abbreviature latine ed italiane, de Adriano Cappelli. $2^{\text {nd }}$ ed. Louvain: Publications Universitaires.

Pollard, Graham. 1978. "The Pecia System in the Medieval Universities." In Medieval Scribes, 
Manuscripts \& Libraries: Essays Present to N. R. Ker, 145-161. Edited by M. B. Parks and Andrew G. Watson. London: Scolar Press.

Pratt, Robert A. 1977. "Some Latin Sources of the Nonnes Preest on Dreams." Speculum 52: 538-570.

Schmitt, F. S., ed. 1968. S. Anselm Cantuariensis Archiepiscopi Opera Omnia. Stuttgart-Bad Cannstatt: Friedrich Fromann Verlag.

Southern, R. W. 1963. St. Anselm and his Biographer. Cambridge: Cambridge University Press.

Streveler, Paul and Katherine Tachau, ed. 1995. Seeing the Future Clearly: Questions on Future Contingents by Robert Holcot. Toronto: Pontifical Institute of Mediaeval Studies.

Thorndike, Lynn. 1944. University Records and Life in the Middle Ages. New York: Columbia University Press.

Williams, Thomas. 2000. "A Most Methodical Lover? On Scotus's Arbitrary Creator." Journal of the History of Philosophy 38: 169-202. . 2002. Three Philosophical Dialogues: On Truth, On Freedom of Choice, On the Fall of the Devil. Indianapolis: Hackett Publishing Company. . Forthcoming. "The Life and Works of John Duns the Scot." In The Cambridge Companion to Duns Scotus, ed. Thomas Williams. Cambridge: Cambridge University Press.

Wolter, Allan B. 1996. “Reflections about Scotus's Early Works.” In Ludger Honnefelder, Rega Wood, and Mechthild Dreyer, eds., John Duns Scotus: Metaphysics and Ethics, 37-57. Leiden: E. J. Brill. 